\title{
Naphthalene induced acute hemolysis in a G6PD deficient bangladeshi boy - a case report
}

\begin{abstract}
Naphthalene is a chemical which is used widely as moth repellent, insecticides and as a deodorant in lavatories worldwide. This report presents a 3 years old Bangladeshi boy, who used to play with naphthalene moth-balls for last 7 days and inquisitively ingested part of a naphthalene ball and was admitted with recurrent vomiting, abdominal pain, headache, fever, passage of dark cola colored urine and jaundice. The child had no past history of jaundice or any episodes of Hemolysis. Features of severe intravascular haemolysis with neutrophilic leukocytosis were detected. His Glucose 6 phosphate dehydrogenase (G6PD) activity was found below normal and was diagnosed as G6PD deficiency disorder. He was treated with IV saline infusion, packed cell transfusion and oral anti-oxidant (Vit A, C, E) therapy. The aim of this case report is to highlight and also to aware about the toxicity of this common household naphthalene especially in G6PD deficient patient.
\end{abstract}

Volume 2 Issue 2 - 2016

\author{
Sarabon Tahura \\ Department of Pediatric Hematology and Oncology, Bangladesh \\ Institute of Child Health (BICH), Dhaka Shishu (Children) \\ Hospital, Bangladesh
}

\begin{abstract}
Correspondence: Sarabon Tahura, Department of Pediatric Hematology and Oncology, Institute of Child Health (BICH), Dhaka Shishu (Children) Hospital, Sher-e-Bangla nagar, Dhaka, Bangladesh, Email drsarabon@yahoo.com
\end{abstract}

Received: April 0I, 2016 | Published: November 10, 2016

Keywords: naphthalene, hemolysis, g6pd deficiency disorder

\section{Introduction}

Naphthalene (C10 H8) is a bicyclic aromatic hydrocarbon having 128 molecular weight. ${ }^{1}$ Usually it is used as a deodorant in lavatories, moth repellent and as insecticides, mite powders and vermifuges. ${ }^{2}$ In Bangladesh, a developing country, naphthalene is very popular and widely used moth repellent. People use it freely in household as it is very cheap and easily available. Naphthalene is marketed commercially in the form of various attractive shapes like balls, flakes, stars etc and its sparkling bright white colour is also very appealing to children. So, exposure can easily occur to them through inhalation, dermal absorption or ingestion and may cause severe toxicities like severe Hemolysis. But most of the people are unaware about its hazards. The characteristic signs of naphthalene toxicities are headache, vomiting, diarrhea, abdominal pain, fever, altered mental status and consequences of acute intravascular Hemolysis leading to anemia, leukocytosis, hematuria, jaundice and liver and kidney dysfunction. ${ }^{1}$ Cerebral oedema, confusion, convulsion, coma and death may occur. ${ }^{3}$ Commercially available one mothball contains $0.5-5 \mathrm{gm}$ of naphthalene depending upon its size. The lethal dose of ingested naphthalene is 2 grams in children and in adults 5-15grams. ${ }^{4}$ But small naphthalene mothball ingestion may be very dangerous and potentially lethal for the G6PD deficient individuals. ${ }^{5}$ Vales et al. ${ }^{6}$ reported 21 neonates who developed Hemolysis after exposure to naphthalene, 12 of them were diagnosed as G6PD deficiency disorder. So, it should be our concern to aware people about the hazards of naphthalene, especially in G6PD deficient individual.

\section{Case report}

A 3 years old Bangladeshi boy, 1st issue of non-consanguineous parents, was admitted in the Hospital, 36 hours after ingestion of naphthalene mothball. For last 7 days the boy used to play with naphthalene mothball which were kept for household use and inquisitively he ingested part of a naphthalene ball. One hour after naphthalene ingestion, the boy developed profuse vomiting, abdominal pain and diarrhea. The next day, he also developed high grade fever with headache and mother gave him oral paracetamol. Fever and headache was partially subsided but the child developed dark cola colored urine along with yellowish discoloration of eyes and skin. The child had no previous history of jaundice or any experience of bleeding prior this episode and he had no family $\mathrm{H} / \mathrm{O}$ hemolytic anemia or bleeding Disorder. On admission, the child was conscious, febrile (temp: 1010F), severely pale, mildly icteric, normotensive (BP: $80 / 60 \mathrm{~mm}-\mathrm{Hg}$ ) and a cyanotic. Pulse was $100 / \mathrm{min}$ and respiratory rate was $22 / \mathrm{min}$. Abdomen was mildly tender but soft. There was no hepato-spleenomegaly and other systemic examinations including CNS examination revealed normal findings. On the day of admission, lab investigations of the child revealed $\mathrm{Hb}-5.3 \mathrm{gm} / \mathrm{dl}, \mathrm{MCV}-75 \mathrm{fl}$, total Leukocyte count $21000 / \mathrm{mm}^{3}$, platelet count $215 \times 10^{9} / \mathrm{L}$. Differential count of WBC showed nutrophilic leukocytosis and platelet distribution was normal with reticulocytosis. Peripheral Blood film showed microcytosis, anisocytosis and polychromatophilia but Heinz body was not detected. His total bilirubin was $4.9 \mathrm{mg} / \mathrm{dl}$ with the indirect fraction measuring $4.2 \mathrm{mg} / \mathrm{dl}$. Urine for $\mathrm{Hb}$ revealed presence of $\mathrm{Hb}$ suggesting hemoglobinuria. Coombs test was negative and no malaria parasite was detected on thick films. Further investigations revealed Liver enzymes, Renal functions and Coagulation profile were normal but Glucose-6-phosphate dehydrogenase (G6PD) level was below normal that was $4.3 \mathrm{IU} / \mathrm{gm} \mathrm{Hb}$, where the normal reference range was 6.97-20.5. The child was diagnosed as G6PD deficiency disorder. The child was treated by $\mathrm{I} / \mathrm{V}$ infusion with normal saline, two units of packed RBC and oral vit A, C, E as anti-oxidant. Pyrexia was resolved by $2^{\text {nd }}$ day. His urine color gradually became clear by third day and his $\mathrm{Hb}$ level was increasing gradually and was $9.7 \mathrm{gm} / \mathrm{dl}$ at $5^{\text {th }}$ day of admission. The child was discharged on $6^{\text {th }}$ day of admission without any renal or neurological sequel. On discharge, general along with genetic Counseling was done to the parents regarding G-6-PD deficiency disorder. Advise for continue oral antioxidant (vit A,C,E) was also given and a list containing the name of drugs, foods and substances which should be avoided was supplied to the parents. One month after discharge on F/U appointment, the child was well alert but mildly pale and that time his $\mathrm{Hb}$ level was $9.4 \mathrm{mg} / \mathrm{dl}$.

\section{Discussion}

Acute Hemolysis due to exposure of naphthalene mothball has been reported worldwide. ${ }^{1-6}$ But from Bangladesh naphthalene toxicity is rarely reported. In 2012 for the $1^{\text {st }}$ time Rahman et al. ${ }^{7}$ reported a 22 years Bangladeshi woman having hemolytic anemia 
after accidental ingestion of coconut oil containing naphthalene. But the woman had normal G6PD level. But in the current reported case, acute Hemolysis occurred in a 3 years old G6PD deficient Bangladeshi child after naphthalene exposure. Interestingly, this G6PD deficient child was undiagnosed at the time of presentation; even he had no past history of bleeding episode. The diagnosis of G6PD deficiency was disclosed after laboratory confirmation. Naphthalene is well absorbed following oral exposure; it can also be absorbed through the skin or by inhalation. ${ }^{1}$ In the present case, the child used to play with naphthalene moth balls, so some extent of dermal absorption was taking place to the child for last 7 days and as the child was G6PD deficient, he had severe hemolytic episodes even after taking only very small part of a naphthalene moth ball. Here, naphthalene acted as oxidant stress causing triggering agent for Hemolysis. Naphthalene induces enhanced production of free oxygen radicals, resulting in lipid per oxidation and deoxyribonucleic acid damage. ${ }^{1}$ On the other hand, G6PD deficient patients have low tolerance to oxidative stress. ${ }^{8}$ Previous different studies ${ }^{9,10}$ also showed naphthalene exposure as a possible stressor for precipitation the onset of acute Hemolysis in previously well children as well as for those who are already diagnosed as having G6PD deficiency. As, naphthalene exposure is a threat, not only for G6PD deficient individuals but also for all children as well as adult, it should be banned for household use.

\section{Acknowledgements}

None.

\section{Conflict of interest}

The author declares no conflict of interest.

\section{References}

1. Lim HC, Poulose V, Tan HH. Acute naphthalene poisoning following the non-accidental ingestion of moyh balls. Singapore Med J. 2009;50(8):298-301.

2. Chusid E, Fried CT. Acute hemolytic anemia due to naphthalene ingestion. Am Dis Child. 1989;143:612-614.

3. Gidron E, Leurer J. Naphthalene poisoning. Lancet. 1956;267(6910):228 230 .

4. Hodge GO. Clinical toxicology of commercial product. 1st ed. USA: McGraw Hill; 1957. p. 1-160.

5. Goldfrank LR, Bania TC. Comphor and mothball. In: Goldfrank LR, Flomenbaum NE, Lewin NA, et al. editors. Goldfrank's Toxicologic Emergencies. USA: Appleton and Lange; 1994. 1095 p.

6. Vales T, Psyros AD, Phaedrom F. Acute hemolysis due to naphthalene inhalation. J Pediatr. 1963;63(5):904-915.

7. Rahman, Mowla, Rahim A, et al. Severe haemolytic anaemia due to ingestion of naphthalene (mothball) containing coconut oil. Journal of the physicians and surgeons Pakistan. 2012;22(11):740-741.

8. Rieders F, Brieger H. Hemolytic action of naphthalene and its oxidation products. Pediatrics. 1951;7:725-727.

9. Santucci K, Binita S. Association of naphthalene with acute hemolytic anaemia. Academic emergency medicine. 2000;7(1):42-47.

10. Siegel E, Wason S. Mothball toxicity. Pediatr clin North Am. 1986;33(2):369-374. 